Human bioturbation, and the subterranean landscape of the Anthropocene Jan Zalasiewicz ${ }^{*}$, Colin N. Waters ${ }^{2}$ and Mark Williams ${ }^{1}$

1. Department of Geology, University of Leicester, University Road, Leicester LE1 7RH, UK.

2. British Geological Survey, Keyworth, Nottingham, NG12 5GG, UK.

*Corresponding author: e-mail jaz1@le.ac.uk 


\title{
Human bioturbation, and the subterranean landscape of the Anthropocene
}

\begin{abstract}
Bioturbation by humans ('anthroturbation'), comprising phenomena ranging from surface landscaping to boreholes that penetrate deep into the crust, is a phenomenon without precedent in Earth history, being orders of magnitude greater in scale than any preceding non-human type of bioturbation. These human phenomena range from simple individual structures to complex networks that range to several kilometres depth (compared with animal burrows that range from centimetres to a few metres in depth), while the extraction of material from underground can lead to topographic subsidence or collapse, with concomitant modification of the landscape.
\end{abstract}

Geological transformations include selective removal of solid matter (e.g. solid hydrocarbons, metal ores), fluids (natural gas, liquid hydrocarbons, water), local replacement by other substances (solid waste, drilling mud), associated geochemical and mineralogical changes to redox conditions with perturbation of the water table and $\mathrm{pH}$ conditions and local shock-metamorphic envelopes with melt cores (in the case of underground nuclear tests). These transformations started in early/ mid Holocene times, with the beginning of mining for flint and metals, but show notable inflections associated with the Industrial Revolution (ca $1800 \mathrm{CE}$ ) and with the 'Great Acceleration' at 1950 CE, the latter date being associated with the large-scale extension of this phenomenon from sub-land surface to sub-sea floor settings.

Geometrically, these phenomena cross-cut earlier stratigraphy. Geologically, they can be regarded as a subsurface expression of the surface chronostratigraphic record of the Anthropocene. These subsurface phenomena have very considerable potential for long-term preservation. 
Keywords: Anthropocene; bioturbation; mining; boreholes; underground nuclear tests

\section{Contents}

1. Introduction

2. The palaeontological context: comparisons with non-human bioturbation.

3. Surface anthroturbation

4. Shallow anthroturbation

5. Deep anthroturbation

$5.1 \quad$ Mining

5.2 Boreholes

5.3 Storage facilities

6. Preservation potential of deep anthroturbation fabrics

7. Temporal distribution of subsurface bioturbation

8. Discussion

Acknowledgements

References

\section{Introduction}

Human modification of the surface of the Earth is now extensive. Clear and obvious changes to the landscape, soils and biota are accompanied by pervasive and important changes to the atmosphere and oceans. These have led to the concept of the Anthropocene (Crutzen and Stoermer, 2000; Crutzen, 2002), which is now undergoing examination as a potential addition to the Geological Time Scale (Zalasiewicz et al., 2008; Williams et al., 2011; Waters et al., 2014). These changes are significant geologically, and have attracted wide interest 
because of the potential consequences, for human populations, of living in a world changed geologically by humans themselves.

Humans have also had an impact on the underlying rock structure of the Earth, for up to several kilometres below the planetary surface. Indirect effects of this activity, such as the carbon transfer from rock to atmosphere, are cumulatively of considerable importance. However, the extent and geological significance of subsurface crustal modifications are commonly neglected: out of sight, out of mind. It is a realm that ranges from difficult to impossible to gain access to or to experience directly.

However, any deep subsurface changes, being well beyond the reach of erosion, are permanent on any kind of human timescale, and of long duration even geologically. Hence, in imprinting signals on to the geological record, they are significant as regards the human impact on the geology of the Earth, and therefore as regards the stratigraphic characterization of the Anthropocene.

This phenomenon is not something that falls neatly into any chronostratigraphic classification, given that relationships here are cross-cutting, not superpositional, and they typically represent more or less in situ modification of older rocks, rather than the creation of new strata at the surface. The large-scale 'anthroturbation' resulting from mining and drilling has more in common with the geology of igneous intrusions than sedimentary strata, and may be separated vertically from the Anthropocene surface strata by several kilometres.

Here, we provide a general overview of subsurface anthropogenic change and discuss its significance in the context of characterising a potential Anthropocene time interval.

\section{The palaeontological context: comparisons with non-human bioturbation.}


Bioturbation may be regarded as a primary marker of Phanerozoic strata, of at least equal rank to body fossils in this respect. The appearance of animal burrows was used to define the base of the Cambrian, and hence of the Phanerozoic, at Green Point, Newfoundland (Brasier et al., 1994; Landing, 1994), their presence being regarded as a more reliable guide than are skeletal remains to the emergence of motile metazoans.

Subsequently, bioturbated strata became commonplace - indeed, the norm - in marine sediments and then, later in the Palaeozoic, bioturbation became common in both freshwater settings and (mainly via colonization by plants) on land surfaces. A single organism typically leaves only one record of its body in the form of a skeleton (with the exception of arthropods, that leave several moult stages), but can leave very many burrows, footprints or other traces. Because of this, trace fossils are more common in the stratigraphic record than are body fossils in most circumstances. Trace fossils are arguably the most pervasive and characteristic feature of Phanerozoic strata. Indeed, many marine deposits are so thoroughly bioturbated as to lose all primary stratification (e.g. Droser and Bottjer, 1986).

In human society, especially in the developed world, the same relationship holds true. A single technologically advanced (or, more precisely, technologically supported and enhanced) human with one preservable skeleton is 'responsible' for very many traces, including his or her 'share' of buildings inhabited, roads driven on, manufactured objects used (termed technofossils by Zalasiewicz et al., 2014), and materials extracted from the Earth's crust; in this context more traditional traces (footprints, excreta) are generally negligible (especially as the former are typically made on artificial hard surfaces, and the latter are generally recycled through sewage plants).

However, the depths and nature of human bioturbation relative to non-human bioturbation is so different that it represents (other than in the nature of their production) an entirely different phenomenon. Animal bioturbation in subaqueous settings typically affects the top few centimetres to tens of 
centimetres of substrate, not least because the boundary between oxygenated and anoxic sediment generally lies close to the sediment-water interface. The deepest burrowers include the mud shrimp Callianassa, reach down to some 2.5. $\mathrm{m}$ (Ziebis et al., 1996). Below subaerial surfaces, animal burrows are not very much deeper, the deepest burrowers typically cited being wolves and foxes, at up to four metres, though aestivating Nile crocodiles (Crocodylus niloticus) may reach up to $12 \mathrm{~m}$ depth (Voorhies, 1975). Prehistoric animals likely did not attain significantly greater depths; dinosaur burrows, for example, were long unrecorded, and the single example known (Varrichio et al., 2007) is not much more than $20 \mathrm{~cm}$ across and lies less than a metre below the palaeo-land surface.

Plant roots can penetrate depths an order of magnitude greater, especially in arid regions: up to $68 \mathrm{~m}$ for Boscia truncata in the Kalahari desert (Jennings, 1974). They can be preserved as rootlet traces, generally through diagenetic mineral precipitation or remnant carbon traces. Roots, though, typically infiltrate between sediment grains, limiting the amount of sediment displacement and hence disruption to the rock fabric.

At a microscopic level, too, there is a 'deep biosphere' composed of sparse, very slowly metabolizing microbial communities that can exist in pore spaces and rock fractures to depths of 1-2 kilometres (e.g. Parkes et al., 1994). These may mediate diagenetic reactions where concentrations of nutrients allow larger populations (such as the 'souring' of oil reservoirs) but otherwise leave little trace in the rock fabric. Very rarely, these communities have been found to be accompanied by very deep-living nematode worms (Borgonie et al., 2011), but these seem not to affect the rock fabric, and we know of no reports of their fossil remains or any traces made by them.

The extensive, large-scale disruption of underground rock fabrics, to depths of $>5$ kilometres, by a single biological species, thus represents a major geological innovation (cf. Williams et al., 2014). It has no analogue in the Earth's 4.6 billion year history, and possesses some sharply distinctive features: for instance, the structures produced reflect a wide variety of human behaviour effected through 
tools or more typically mechanized excavation, rather than through bodily activity. Hence, the term 'anthroturbation' (Price et al., 2011; see also Schaetzl and Anderson 2005 for use in soil terminology) is fully justified, and we use this in subsequent description below.

\section{Surface anthroturbation}

This is extensive, and distantly analogous to surface traces left by non-human organisms. It includes surface excavations (including quarries) and constructions, and alterations to surface sedimentation and erosion patterns, in both urban and agricultural settings. Its nature and scale on land has been documented (e.g. Hooke, 2000, Hooke et al., 2013; Wilkinson, 2005; Price et al., 2011; Ford et al., 2014) and it extends into the marine realm via deep-sea trawling (e.g. Puig et al. 2012) and other submarine constructions. Here we simply note its common presence (Hooke et al. (2013) estimated that humans have modified $>50 \%$ of the land surface) as our focus is on the subsurface phenomena that descend from this anthropogenically modified surface level.

\section{Shallow anthroturbation}

Shallow anthroturbation extends from metres to tens of metres below the surface, and includes all the complex subsurface machinery (sewerage, electricity and gas systems, underground metro systems, subways and tunnels) that lies beneath modern towns and cities. The extent of this dense array is approximately coincident with the extent of urban land surfaces (some $3 \%$ of land area: Global Rural Urban Mapping: http:// sedac.ciesin.columbia.edu/data/collection/grump-v1 ; though see also Klein Goldewijk et al., 2010).

Shallow anthroturbation also includes shallow mines, water wells and boreholes, long-distance buried pipes for hydrocarbons, electricity and water and tile drains in agricultural land. The extensive exploitation of the subsurface environment, as symbolised by the first underground railway system in the 
world (in London in 1863) was chosen as a key moment in human transformation of the Earth, and suggested as a potential 'golden spike' candidate, by Williams et al. (2014). These buried systems, being beyond the immediate reach of erosion, have a much better chance of short- to mediumterm preservation than do surface structures made by humans. Their long-term preservation depends on them being present on descending parts of the crust, such as on coastal plains or deltas.

\section{Deep anthroturbation}

Deep anthroturbation extends from hundreds to thousands of metres below the ground surface. It includes deep mining for coal and a variety of minerals, and deep boreholes, primarily for hydrocarbons. Other types of anthroturbation here include deep repositories for a variety of waste, including nuclear waste, and the underground nuclear bomb test sites. There are significant differences in the geological effects of mining and drilling, and so these will here be treated separately.

\subsection{Mining}

In mining, the excavations are made by a combination of human and machine (long-wall cutters in coal-mining, for instance), and the scale of the excavation is sufficient for access by humans (Waters et al., 1996). Most deep mining takes place at depths of a few hundred metres, though in extreme circumstances it extends to ca $5 \mathrm{~km}$, as in some gold mines in South Africa (Malan and Basson, 1998) - a phenomenon made possible by a combination of the high value to humans of gold and the very low geothermal gradient in that part of the world. In mature areas for mineral exploitation, such as the UK, large parts of the country are undermined for a variety of minerals (Fig. 1: Jackson, 2004).

Mining typically involves the underground extraction of solid materials, leaving voids underground in a variety of geometrical patterns (Fig. 2). When voids collapse, this leaves a fragmented/ brecciated layer in place of the original 
material. With this, subsidence of the overlying ground surface takes place, and this may reach metres (or tens of metres) in scale, depending on the thickness of the solid stratum extracted.

\subsection{Boreholes}

In boreholes, the perturbation to rock fabric is made by drilling equipment, remote from the humans that guide the process, and the depths reached (especially for hydrocarbons) commonly attain several kilometres. (e.g., the Seal Sands borehole is the deepest borehole in UK at 4194 m; the Kola Superdeep Borehole at 12,262 $\mathrm{m}$ is the deepest borehole in the world, whereas Sakhalin-1 at $12,345 \mathrm{~m}$ is the longest). Here, changes to the rock fabric include the drilling of the borehole itself, together with any associated caving-in of the hole, especially where poorly indurated rocks are drilled. Ancillary changes include infiltration of drilling mud into porous rock, and the addition to the rock mass of any casing left in the hole. Boreholes are no longer simply vertical holes, but now may involve arrays of carefully directed low-angle or horizontal holes steered so as to fully exploit underground resources. Figure 3 shows the $\sim 1$ million boreholes in Great Britain colour-coded by depth.

By contrast with mining, the material extracted through boreholes is in fluid form (liquid or gas), replacing oil, for instance by water drawn in from adjacent rocks (or with high-pressure carbon dioxide pumped down for sequestration or simply to enhance oil recovery). These changes to pore fluid composition may nowadays be tracked in real time with geophysical methods, and may be associated both with diagenetic mineralization and with topographic changes at the surface.

A specific variant is represented by the $\sim 1500$ boreholes drilled in some restricted parts of the world for underground nuclear test explosions (http:// en.wikipedia.org/ wiki/ Nuclear weapons testing ). The holes here are mostly obliterated by a rather larger trace, comprising a mass of strongly shock- 
brecciated rock surrounding a melt core (both these facies currently being strongly radioactive), commonly being surrounded by roughly circular fault systems, outlining surface crater systems that, in the Yucca Flats test site, reach several hundred metres across (Grasso, 2000; NNSA, 2005). The Cannikin underground test on Amchitka Island in the Aleutian chain generated sufficient melt that, cooled and crystallized, is equivalent to a moderate-sized volcanic lava dome (Eichelberger et al., 2002).

\subsection{Storage facilities}

Increasingly, storage facilities are being constructed in the subsurface, in many cases because it is considered a safer environment to store potentially dangerous materials. These storage facilities may be constructed specifically to hold the materials, or in many cases re-use existing caverns produced during mineral excavation. These facilities are used to temporarily store energy resources, e.g. Liquefied Petroleum Gas or compressed air energy storage, to provide long-term burial of hazardous wastes such as nuclear waste, $\mathrm{CO}_{2}$ sequestration, or the reuse of mined spaces such as halite for the safe preservation of records or armaments stores within a controlled environment.

\section{Preservation potential of deep anthroturbation fabrics}

Deep anthroturbation fabrics are well beyond the reach of weathering and erosion, and thus permanent on geological timescales, even if their expression in the rock is altered diagenetically. They are only likely to be effaced by igneous or high-grade metamorphic processes, or by erosion once they reach the surface.

As with shallow and surface phenomena, anthroturbation fabrics will reach the surface if the crust is eroded following tectonic uplift. Uplift and denudation rates vary considerably, depending on the tectonic setting, but typically do not exceed a couple of millimetres a year (e.g. Abbott et al., 1997; Schlunegger and 
Hinderer, 2002); structures a few kilometres deep will not break the surface for millions to tens of millions of years. Structures on currently stable or descending crust may of course remain preserved below the surface for very much longer, or even permanently.

The expression of deep mines and boreholes (particularly once they reach the surface, in the far geological future) will differ. Mines - particularly those, such as coalmines that exploit stratabound minerals - will show stratigraphicallyrelated patterns of occurrence. Thus, in each of many coal-fields, that today have substantial outcrops and subcrops in many parts of the world (Fig. 2 for the UK), there can be up to several tens of coal seams exploited to depths that may exceed a kilometre. Each of these seams, over that lateral and vertical extent, will be largely replaced by a horizon marked by little or no remnant coal, but considerable brecciation of adjacent strata (while fossilized examples of, say pit props or mining machinery (or the skeletons of pit ponies or even miners) might occasionally be encountered). In between these intensely worked units there will be thick successions of overlying and underlying strata that are effectively pristine, other than being penetrated in a few places by access shafts and exploration boreholes.

Boreholes into present-day oilfields are abundant globally (the total length of oil boreholes, the great majority drilled since the mid-20th century, has been estimated at 50 million km (J.P.M. Syvitski, personal communication), roughly equivalent to the length of the present-day global road network or the distance from the Earth to Mars. For each human on Earth today there is thus a length of oil borehole of some seven metres - their share (on average) in the provision of the liquid energy that helps shape their lives. The density of boreholes in oilfields may be seen, for instance, in the map showing the 50,686 wells drilled to date in American waters of the Gulf of Mexico (see http:// robslink.com/SAS/ democd33/ borehole.htm). Boreholes are structures that in reality penetrate long crustal successions. However, once exhumed in the far future, they may only rarely be encountered in typical rock exposures as lengths of (usually) vertical disruption at decimetre to metre scale in width. 


\section{Temporal distribution of subsurface bioturbation}

From a current perspective, gained from archaeological, historical and modern records, limited shallow mining has taken place from the Neolithic, with, for example, the excavation of shallow pits into Chalk deposits to exploit flintbearing strata, e.g. Grime's Graves, near Thetford, England worked from 3000 BC. As metals began to be used through the Bronze and Iron ages, many mines were excavated around centres of population, to shallow depths, by humans using simple tools. Other excavations included those for burial of human bodies and, in some countries, for water supply.

The extent and depth of mines (for resources) and excavations (e.g. for underground transport systems) expanded rapidly from the Industrial Revolution, with further acceleration from the mid-20 $0^{\text {th }}$ century and expansion from terrestrial to marine settings - as in the expansion of offshore oil exploration and production. The pattern hence mimics (and was instrumental in driving) the stages of geologically significant human modification of the Earth (cf. Waters et al., 2014).

In a deep-time perspective, long after humans have disappeared, sporadically distributed and exposed deep mine/ boreholes traces in the strata of the far future might lie several kilometres stratigraphically below a stratified Anthropocene palaeosurface, and it would take fortuitously good exposure to reveal their continuity. Their precise chronology might only be preserved via cross-cutting relationships (that may also need fortuitous preservation).

However, in terms of the overall place of these phenomena in Earth history, anthroturbation traces, of course, would not appear above stratified Anthropocene deposits.

\section{Discussion}


Modification of the Earth's underground rock structure is not in itself normally something that would be considered as an environmental perturbation (unless it is accompanied by significant surface subsidence), given that this modification takes place below the level of the surface biosphere, within 'inert' rock. However, this form of anthropogenic modification arguably has the highest longterm preservation potential of anything made by humans, often approaching $100 \%$ (until the trace eventually reaches the surface). In affecting rock structure and therefore the Earth's geology, it is a component of the Anthropocene concept.

As with a number of other aspects of the proposed Anthropocene, this is a geologically novel phenomenon, with no very close analogues in the history of our planet. Of the analogues that may be put forward - igneous or large-scale sedimentary intrusions, for instance, or spontaneous underground combustion of coal seams - none are biological in origin, for no other species has penetrated to such depths in the crust, or made such extensive deep subterranean changes. It is therefore another feature that separates the Anthropocene clearly from preceding periods, and is further evidence of a 'step change' in Earth history (cf. Williams et al., 2014; Zalasiewicz et al., 2014).

This presents potential technical problems, as regards classification within a physical chronostratigraphic unit: a potential Anthropocene Series. Such units are typically stratiform, and based upon superposition (where Upper=Younger and Lower=Older). However, at the present time, the deep, cross-cutting roots of the potential Anthropocene Series can, for practical purposes, be effectively resolved in both time and space. Their significance can only grow in the future, as humans continue to mine the Earth to build their lives at the surface.

\section{References}


Abbott, L.D., Silver, E.A., Anderson, R.S., Ingle, J.C., Kling, S.A., Haig, D., Small, S., Galewsky, J., Sliter, W. 1997. Measurement of tectonic surface uplift rate in a young collisional mountain belt. Nature 385, 501-507.

Borgonie, G., Garcia-Moyano, A., Litthauer, D., Bert, W., Bester, E., van Heerden, E., Möller, C., Erasmus, M., Onstott, T.C. 2011. Nematoda from the terrestrial deep subsurface of subsurface of south Africa. Nature 474, 79-82.

Brasier, M., Cowie,J.W., Taylor, M. 1994. Decision on the Precambrian-Cambrian boundary stratotype. Episodes, 17, 95-100.

Crutzen, P.J., Stoermer, E.F. 2000. The "Anthropocene". Global Change Newsletter, 41, 17-18.

Crutzen, P.J. 2002. Geology of Mankind. Nature, 415, 23.

Droser, M.L., Bottjer, D.J. 1986. A semiquantitative field classification of ichnofabric. Journal of Sedimentary Research 56, 558-559.

Eichelberger, J., Freymueller, J., Hill, G., Patrick, M. 2002. Nuclear stewardship: lessons from a not-so-remote island. Geotimes, March 2002 (web feature).

Ford, J.R., Price, S.J., Cooper, A.H., Waters, C.N. 2014. An assessment of lithostratigraphy for anthropogenic deposits. In: Waters, C.N., Zalasiewicz, J., Williams, M., Ellis, M.A. \& Snelling, A. (Eds) A Stratigraphical Basis for the Anthropocene. Geological Society, London, Special Publications, 395,55-89. Grasso, D.N. 2000. Geological effects of underground nuclear testing. United States Geological Survey Open-File Report 00-176, 20 pp.

Hawkins, W., Wohletz, K. 1997. Ground-based visual Inspection for CTBT Verification. Los Alamos National Laboratory Report LA-UR-97-2928, 37 pp.

Hooke, R. LeB. 2000. On the history of humans as geomorphic agents. Geology, 28, 843-846.

Hooke, R. LeB., Martín-Ducqe, J.F., Pedraza J. 2013. Land transformation by humans: a review. GSA Today 22 (12), 4-10.

Jackson, I. 2004. Britain beneath our feet. (Keyworth, Nottingham: British Geological Survey Occasional Publication No. 4).

Jennings, C.M.H. 1974. The Hydrogeology of Botswana. PhD thesis, University of Natal. 
Klein Goldewijk K., Beusen A., Janssen P. 2010. Long-term dynamic modeling of global population and built-up area in a spatially explicit way: HYDE 3.1. Holocene, 20(4), 565-573.

Landing, E. 1994. Precambrian-Cambrian global stratotype ratified and a new perspective of Cambrian time. Geology, 22, 179-182.

Malan, D.E., Basson, F.R.P. 1998. Ultra-deep mining: the increased potential for squeezing conditions. The Journal of the South Africa Institute for Mining and Metallurgy, November/ December 1998, 353-363.

NNSA (National Nuclear Security Administration) 2005. Nevada Test Site Guide. NNSA, US Department of Energy, Las Vegas, Nevada. 81 pp.

Parkes, R.J., Cragg, B.A., Bales, S.J., Getliff, J.M., Goodman, K., Rochelle, P.A., Fry, J.C., Weightman, A.J., Harvey, S.M. 1994. Deep bacterial biosphere in Pacific Ocean sediments. Nature 371, 410-413.

Price, S.J., Ford,J.R., Cooper, A.H., Neal, C. 2011. Humans as major geological and geomorphological agents in the Anthropocene: the significance of artificial ground in Great Britain. Philosophical Transactions of the Royal Society, A2011 369, 1056-1084, doi: 10.1098/ rsta.2010.0296.

Puig, P., Canals, M., Company, J.B., Martin, J., Amblas, D., Lastras, G., Palanques, A., Calafat, A.M. 2012. Ploughing the deep sea floor. Nature, 489, 286-289.

Schaetzl, R. J. and Anderson, S. 2005. Soils: Genesis and Geomorphology. Cambridge University Press, 817 pp.

Schlunegger, F. \& Hinderer, M. 2002. Crustal uplift in the Alps: why the drainage pattern matters. Terra Nova 13, 425-432.

Varricchio, D.J., Martin, A.J., Katsura, Y. 2007. First trace and body fossil evidence of a burrowing, denning dinosaur. Proceedings of the Royal Society B274, 1361-1368.

Voorhies, M.R. 1975. Vertebrate burrows. In: Frey, R.W. (Ed.) The Study of Trace Fossils, 325-350. Springer Berlin Heidelberg.

Waters, C N., Northmore, K., Prince, G., Bunton, S., Butcher, A., Highley, D.E., Lawrence, D.J.D., Snee, C.P.M. 1996. Volume 2: A Technical Guide to Ground Conditions. In: Waters, C.N., Northmore, K., Prince, G. \& Marker, B.R. (Eds) 1996. A geological background for planning and development in the City of 
Bradford Metropolitan District. British Geological Survey Technical Report WA/ $96 / 1$.

Waters, C.N., Zalasiewicz, J., Williams, M., Ellis, M. A., Snelling, A. 2014. A stratigraphical basis for the Anthropocene? In: Waters, C.N., Zalasiewicz, J., Williams, M., Ellis, M.A., Snelling, A. (Eds) A Stratigraphical Basis for the Anthropocene. Geological Society, London, Special Publications, 395, 1-21.

Wilkinson, B.H. 2005. Humans as geologic agents: A deep-time perspective. Geology, 33, 161-164.

Williams, M., Zalasiewicz, J., Haywood, A., Ellis, M. (Eds) 2011. The Anthropocene: a new epoch of geological time? Philosophical Transactions of the Royal Society 369A, 833-1112.

Williams, M., Zalasiewicz, J., Waters, C.N., Landing, E. 2014. Is the fossil record of complex animal behaviour a stratigraphical analogue for the Anthropocene? In: Waters, C.N., Zalasiewicz, J., Williams, M., Ellis, M.A., Snelling, A. (Eds) A Stratigraphical Basis for the Anthropocene. Geological Society, London, Special Publications, 395, 143-148. First published online October 25, 2013.

Zalasiewicz, J., Williams, M., Waters, C.N., Barnosky, A.D., Haff, P. 2014. The technofossil record of humans. Anthropocene Review 1, 34-43.

Zalasiewicz, J., Williams, M., Smith, A., Barry, T.L., Coe, A.L., Bown, P.R., Brenchley, P., Cantrill, D., Gale, A., Gibbard, P., Gregory, F.J., Hounslow, M., Kerr, A.C., Pearson, P., Knox, R., Powell, J., Waters, C., Marshall, J., Oates, M., Rawson, P., Stone, P. 2008. Are we now living in the Anthropocene? Geological Society of America Today, Vol. 18, 4-8.

Ziebis, W., Forster, S., Huettel, M., Jørgensen, B.B. 1996. Complex burrows of the mud shrimp Callianassa truncata and their geochemical impact on the sea bed. Nature 382, 619-622.

\section{List of figures}

Figure. 1. Areas of ground beneath the UK with subsurface mining and excavation for a variety of rock and mineral resources. From Jackson (2004), the 
source data shows only the presence or absence of underground mining within individual kilometre squares and not the absolute distribution of subsurface workings. British Geological Survey (C) NERC 2004. Contains Ordnance Survey data (C) Crown Copyright and database rights 2014.

Figure 2. Patterns of underground removal of rock in coal mining. From Waters et al. (1996).

Figure 3. Distribution of the $\sim$ one million recorded boreholes in the UK, as stored in the National Geoscience Data Centre collection of onshore boreholes, shafts and well records (http:// www.bgs.ac.uk/ data/ boreholescans/ home.html). British Geological Survey (C NERC 2014. Contains Ordnance Survey data (c Crown Copyright and database rights 2014 .

Figure 4. Three-dimensional sketch of the surface and underground effects of an underground nuclear test, showing surface collapse crater and inferred distribution of underground fracturing, brecciations and melt. Compiled from data in Grasso (2000), NNSA (2005) and Hawkins and Wohletz (1997). 
Acknowledgements: We thank Paolo Tarolli for the invitation to speak on this topic at the European Geosciences Union, Vienna, 2013, and Jon Harbor and one anonymous referee for very useful comments on the manuscript. Simon Price is thanked for his comments. Colin Waters publishes with the permission of the Executive Director, British Geological Survey, Natural Environment Research Council and the support of the BGS's Engineering Geology Science area. 


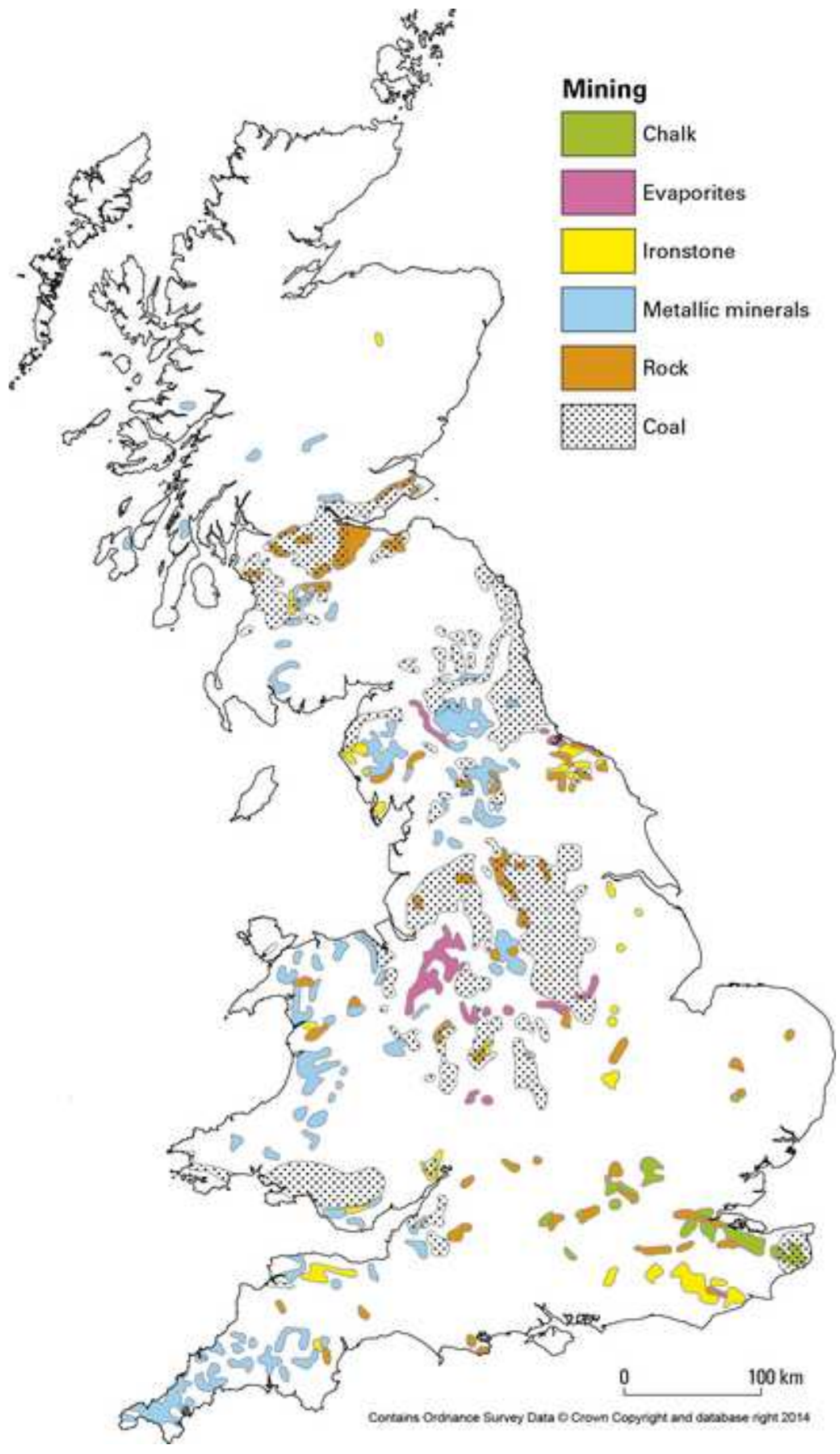




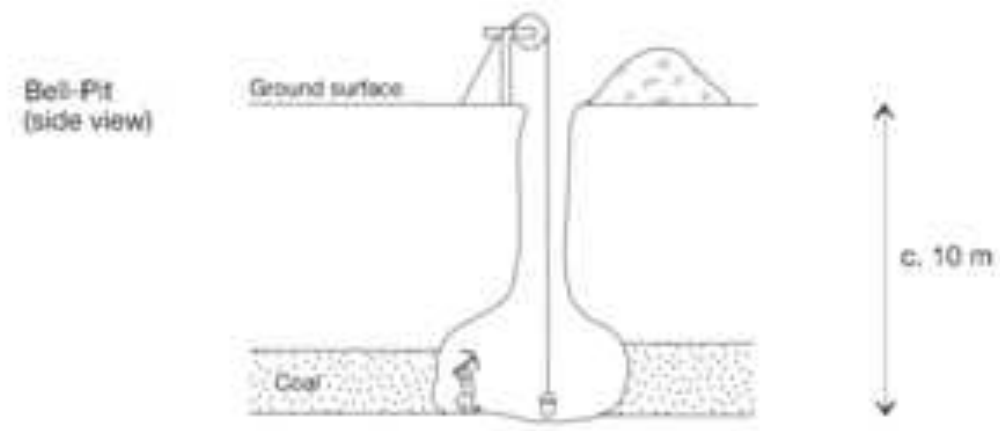

Pitar and stal (plan view)

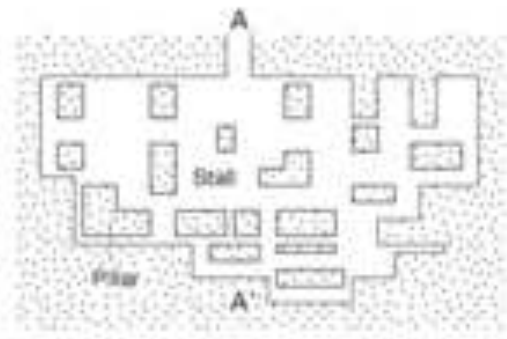

(side verw)
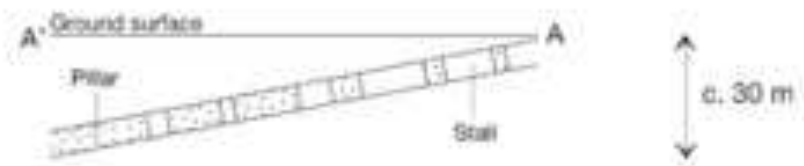

Longwal
(pian view)

B

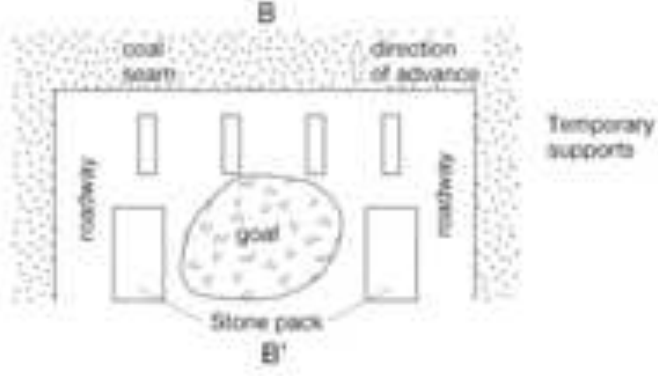

(side view)
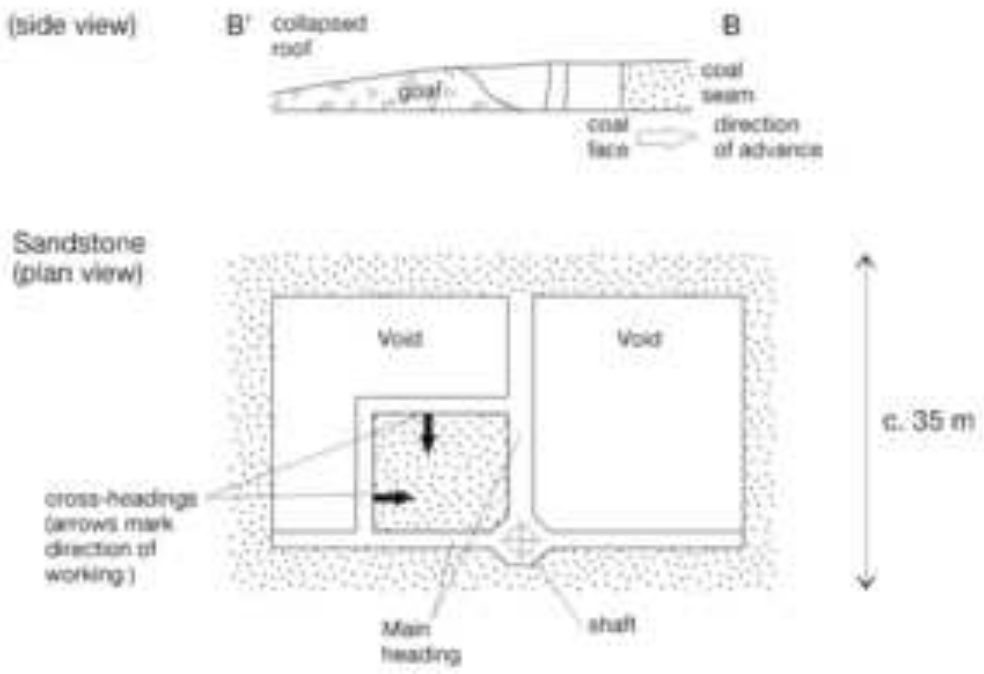


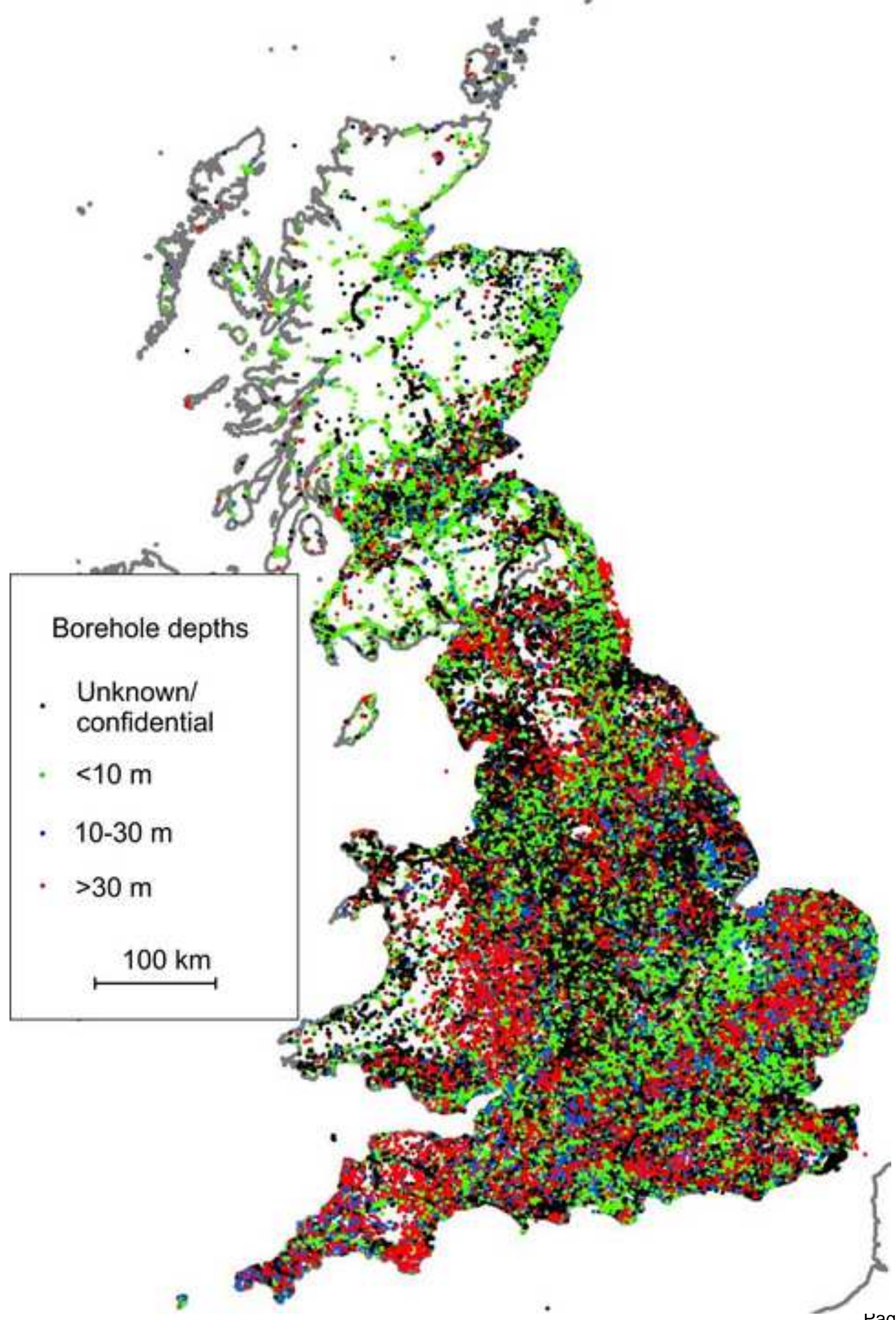


Circular fault system defining collapse crater
Sub-vertical radial and ring fault systems around crater

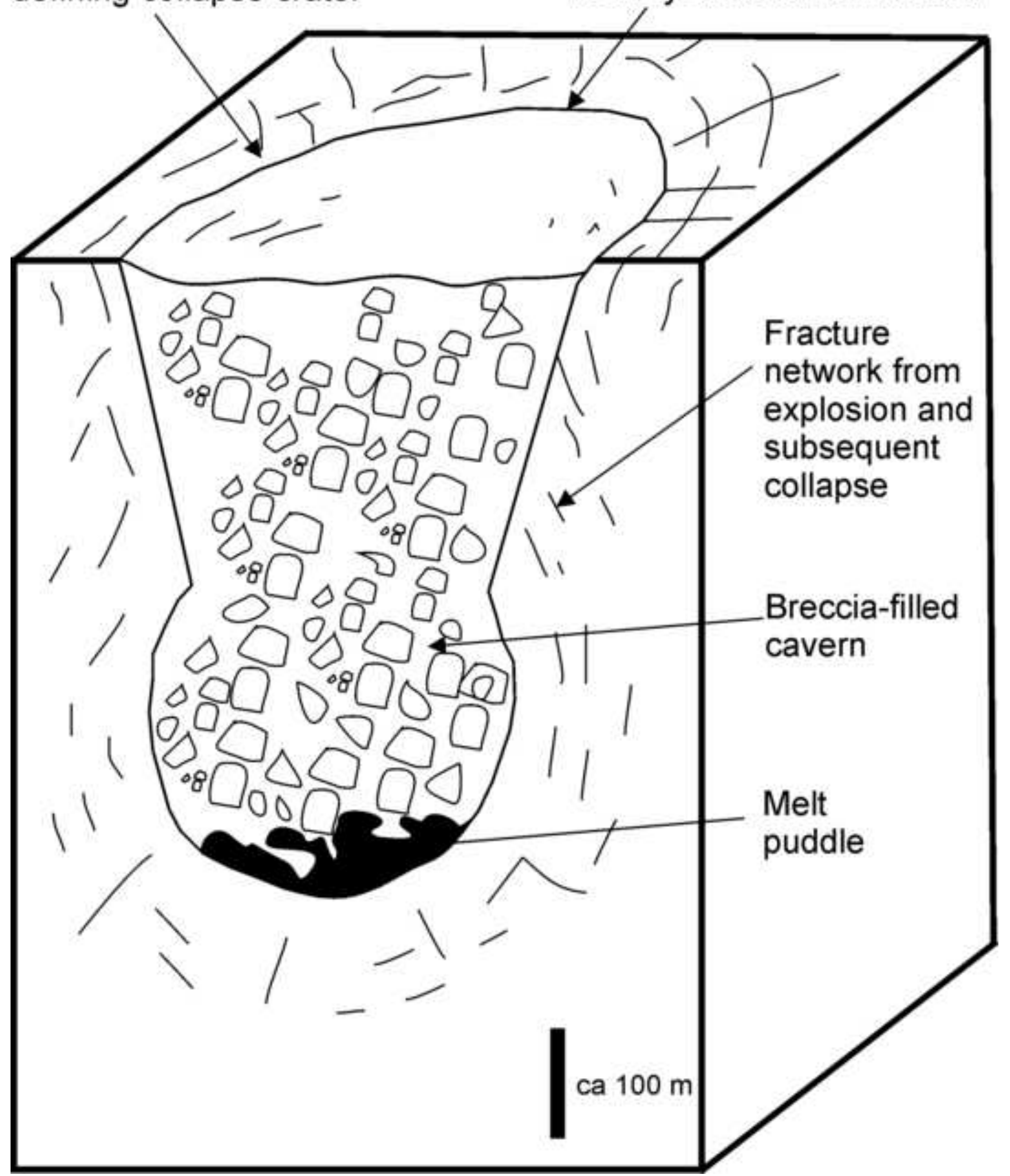




\section{Subterranean Anthropocene - highlights}

- Human mining and drilling into the Earth's crust is 'anthroturbation', analogous to worm and rabbit burrows.

- The human burrows of anthroturbation are gigantic, extending to several kilometres depth.

- $\quad$ Anthroturbation has created unique rocks underground, such as those shattered and melted in underground nuclear tests.

- Anthroturbation structures, being deep underground, are well below the reach of surface erosion.

- $\quad$ Therefore, they will be preserved for millions and even billions of years into the future. 